Saudi Journal of Business and Management Studies Abbreviated Key Title: Saudi J Bus Manag Stud ISSN 2415-6663 (Print) |ISSN 2415-6671 (Online) Scholars Middle East Publishers, Dubai, United Arab Emirates Journal homepage: http://scholarsmepub.com/sjbms/

Original Research Article

\title{
Performance of Conventional and Islamic Banks in the UAE: A Comparative Graphical Ratio Analysis
}

\author{
Manoj Kapur ${ }^{*}$ \\ Pursuing Doctorate of Business Administration from SP Jain School of Global Management United Arab Emirates
}

DOI: $10.36348 / \mathrm{sjbms.2020.v05i01.007}$

| Received: 10.01.2020 | Accepted: 17.01.2020 | Published: 22.01.2020

*Corresponding author: Manoj Kapur

\section{Abstract}

The comparative analysis is conducted to ascertain the performance of Conventional and Islamic Banks operating in the UAE for 5 years from 2014-2018. In order to compare, the author has chosen top 6 Conventional and Islamic banks, respectively, operating in the country. Several ratios are chosen to compare both Islamic and conventional banks. As per the Central Bank of UAE website, banks are classified into locally incorporated banks and branches of foreign banks which have obtained licenses to operate in the UAE. Accordingly, as at 30 June 2019, there are 22 local national banks, 27 branches of foreign banks and 11 wholesale foreign bank branches. Among the locally incorporated banks, there are 6 Islamic banks. Given the consolidation that is happening in the UAE economy, some of the Islamic banks are on the brink of getting merged with other local UAE based banks. Although there is demand for Islamic products, UAE Islamic banks enjoy a relatively small market share as compared to its conventional counterparts.

Keywords: Islamic banks, Conventional Banks, UAE, ratio analysis, financial performance.

Copyright @ 2020: This is an open-access article distributed under the terms of the Creative Commons Attribution license which permits unrestricted use, distribution, and reproduction in any medium for non-commercial use (NonCommercial, or CC-BY-NC) provided the original author and source are credited.

\section{INTRODUCTION}

The role of financial sector and especially banks is pivotal for the economic performance of any country. Banks help to channel peoples saving into investments which thereby help to uplift the economy. In the UAE, both Islamic as well as conventional banks assist in mobilizing the economic interest of its customers. While there are 60 banks in total including local, foreign and wholesale banks, $88 \%$ of the total assets of the UAE banking system is accounted by the UAE National Banks. It is within these national banks that to comparison of conventional and Islamic banks appear.

The working of both banking types differs considerably. While both banks rely on managing deposit vs lending relationship, the way it is handled is different. The products vary as well as the basis of calculating interest on these products. Conventional banks are mainly and directly based on collecting deposits and granting loans. The interest received on granting loans less the interest paid on collecting deposits would be termed as "Net Interest Margin".

On the other hand, Islamic banks conduct business on the basis of Sharia rules, which interalia governs their transactions. Under Islamic Banking, interest is forbidden and is considered as Riba that is forbidden according to rules of Islam. Four main rules govern the investment behavior of Islamic banking, namely [1]:

- There must be absence of an interest based transactions termed as Riba;

- There must be avoidance of speculation in economic activities called Gharar;

- Religious payment of an Islamic tax called Zakat; and finally

- The discouragement of the production of goods and services which contradict the value pattern of Islam termed as Haram. 
There are some major differences between the operating style of conventional and Islamic banks. While most are aware of the interest bearing loan and deposit forming assets and liabilities of the conventional banks; on the liability side of an Islamic bank balance sheet includes qard hassan - opened for savings account. The savings account can also be opened on the basis of Mudaraba or Musharaka principles. As part of the assets, Islamic banks have included three different types of Islamic finance modes.

- Sale based methods which include i.e., Istisna, Murabaha and Salam.

- Products that offer profit sharing participatory methods like Mudaraba, Musharaka and Diminishing Musharaka.

- Islamic leasing product called Ijara.

Hence, there exist significant differences in the product offered by conventional banks and Islamic banks. UAE is home to the oldest Islamic bank of the world, namely, Dubai Islamic Bank, which started operations in 1979. As at 2018, there are 7 full-fledged Islamic banks while some conventional banks also operate Islamic window. CBUAE, FSR [2] stated in terms of total assets, among UAE national banks, Islamic banks represented $23 \%$ while conventional represented $77 \%$. Global Islamic finance assets were forecasted to reach USD 3 trillion by 2018 and consequently Dubai was gearing to become a major Islamic finance hub as it sought to tap the sector's enormous potential. However, in a report published by S\&P Global Rating, the increase in Islamic assets was only $2 \%$ in 2018 as compared to $10 \%$ in 2017 , after decline in sukuk demand. The decrease in the Middle East Markets was mainly attributed to low oil prices and geopolitical risk and hence slow growth of Islamic finance industry is expected.

This research is aimed at comparing several parameters of the conventional banks with the Islamic banks for the years 2014-2018. The performance is measured for 5 years on the basis of different ratio calculation viz liquidity, asset quality, efficiency and leverage. The study is divided into following 5 sections. Section 3 consists of objectives and hypothesis of the proposed study. Section 4 describes the literature review for each ratio to be calculated for liquidity, asset quality, efficiency and leverage of the banking performance (both conventional and Islamic banks). Section 5 describes the data and the methodology used to analyze the data. Section 6 analyses the data and the results. Finally, the conclusion of the study will be presented in the final Section 7.

\section{Objectives and hypothesis of the proposed study}

Various stakeholders are involved in the banking sector. A stakeholder can be described as an individual or group of people who can be directly or indirectly, affected by the actions or performance of the objectives of the firm [3]. There have been several pieces of literature that has identified varied dimensions of CSR: regulators, employees, customers, society, shareholders, media, environment, media and many others [4-6].

Financial performance highlights key growth indicators which are important from regulatory and legal perspective. It also aids in executing prudential actions for any challenges that can affect the growth of the industry. With these indicators corrective actions can be implemented which can aid the entire banking sector. From this study perspective, shareholders would also be interested to know the performance of the bank to assess their potential investment. This will help the investors and shareholders to diversify their investment portfolio. While the aim of the research is to compare performance of conventional and Islamic banks in the UAE, the objectives are met by answering the following research questions:

- Is there substantial variation in liquidity ratios of Conventional and Islamic banks?

- Is there substantial variation in asset quality ratios of Conventional and Islamic banks?

- Is there substantial variation in efficiency ratios of Conventional and Islamic banks?

- Is there substantial variation in leverage ratios of Conventional and Islamic banks?

- Is there substantial variation in performance ratios of Conventional and Islamic banks in relation to liquidity, asset quality, efficiency and leverage?

\section{LITERATURE REVIEW}

The basic parameter to measure performance of any institution is profitability. It is an attribute widely used to measure effectiveness and efficiency with which the operations of the institution are carried out. While profitability can be easily derived through income statement, it is important to consider other aspects like liquidity, asset quality, efficiency and leverage for comparative purposes. Most studies use comparison of several ratios in literature review to benchmark performance among peer groups. For the purpose of this study, financial ratio analysis will be used to compare and measure the performance of the selected banks. Parashar [7] reviewed the conventional and Islamic banks on 5 different dimensions; efficiency, profitability, capital adequacy, leverage and liquidity. His studies were based on the crises period of 2008 and his analysis pointed out that conventional banks were more prone to degradation in liquidity and return on assets while Islamic banks underwent losses in capital adequacy and leverage. During the study period of 2006-2009, the performance of Islamic banks was considered to be better than conventional banks by improving their capital adequacy, earnings to total assets and return on average assets. 
Similar studies were also undertaken in Bahrain by comparing conventional and Islamic banks for the years 1991 to 2001 by Samad [8]. The outcome of the research indicated the credit performance of conventional and islamic banks was different; however, there was few differences in the liquidity and profitability. Alternative study was conducted by Srairi [9] on cost and profit efficiency analysis using stochastic frontier approach. This research was conducted using 71 banks from GCC from 1997 to 2007. The outcome revealed that conventional banks were efficient and far better than their Islamic counterparts.

Zaki [10] observed the certain correlated issues: Ascertaining and explaining the determinants the financial turmoil in the UAE's financial markets and simultaneously considering the impact of the UAE government bailouts on the UAEs economy in the long and short run. The results were that the government was successful to avert financial crises of the the troubled banks through bailouts and reducing government economic activity. The timing of the increase in the leverage risk and reserve adequacy (liquidity risk) of the UAE's economy is consistent with the model's prediction that the government's bailouts and foreign reserve policy played a crucial role in reducing the adverse reaction to the financial crisis during 2007 2008. These judicious developments significantly contributed to the positive outlook in the market. The result was a thriving banking sector with positive confidence of the market participants.

Ibrahim [11] used parameters namely, profitability, liquidity, capital structure, share performance and management capacity to measure the efficiency of 2 banks namely Abu Dhabi Islamic Bank and Dubai Islamic bank in the period between 2003 and 2007. The research outcome stated that in order to maximize their efficiency and profitability both banks have adopted similar strategy and financial tools which will ensure maximum financial feasibility. The result further analyzed that the liquidity of Abu Dhabi Islamic Bank was higher than Dubai Islamic Bank. Moreover, he found that Abu Dhabi Islamic Bank's profitability level is lower than Dubai Islamic bank while capital structure result indicated that the structures for the two banks are almost the same.

Kim and Kim [12] managed to conduct a comparison of the profitability and structure of few commercial banks in the United States of America and Korea. The objective was to analyze the profitability of the sampled banks and used ROE and ROA as measures to ascertain the results. ROE and ROA was used as dependent variables while seven other independent variables viz shareholders' equity to total assets, total loans to total deposits, liquid assets to assets, total borrowed funds to total assets, fixed assets to total assets, a reciprocal value of total assets and reserves for loans to total assets. The research found that banks in the USA are far ahead that banks in Korea in relation to profitability and efficiency. In addition, the findings pointed out that the reserves for capitalization, efficiency, bank size and loan losses were some key factors affecting the bank's profitability in USA and Korea. Zimmerman [13] examined factors affecting community banks efficiency and concluded that the regional conditions and loan portfolio concentration were important factors in community banks performance.

Al-Tamimi, H., \& Hussein, A. [14] investigated certain significant differences in the conventional and Islamic banks in the UAE. They used regression analysis in which ROA and ROE were factored into a model as dependent variables. They also used other external and internal factors as independent variables including: Size, GDP, liquidity, financial development indicator (FIR), cost, branches and concentration. The results indicate that concentration and liquidity were the critical determinants for conventional banks performance. Conversely, number of branches and cost were critical determinants to measure performance of Islamic banks in the UAE.

Aman, A., Sharif, S., \& Arif, I. [15] evaluated and compared the performance of Islamic and conventional banks in Pakistan from 2008 to 2013 (6 years) on efficiency, orientation, stability and asset quality. The research found conventional banks superior to Islamic banks as they had relatively longer years of existence and experience. Further, because Islamic banks are smaller in terms of total asset, the financial ratios of the Islamic banks were widely lower than conventional banks. The conclusion was that Islamic banks were considered less cost efficient but had better asset quality and stability as compared to traditional conventional banks.

Given the surrounding literature, there have been many studies that have utilized ratio analysis for comparing performance of conventional and Islamic banks in the world and in the UAE in specific. While there are many studies on conventional banks, the performance of Islamic banks has not been given much importance. Whether the performance of Islamic banks can be benchmarked to the performance of conventional banks needs to be answered. Is the performance on all dimensions similar or is there problem in one or more dimensions of the performance of the banks. In the absence of adequate literature in this field, the present study is an attempt to fulfil the research gap in the conventional and Islamic banks in the UAE.

\section{DATA AND METHODOLOGY}

The data consists of top 6 Islamic banks and top 6 conventional banks operating in the UAE over the period 2014-2018 (5 years). The conventional banks are - $\quad$ First Abu Dhabi Bank (FAB)*, 
- $\quad$ Emirates NBD (ENBD),

- Abu Dhabi Commercial Bank (ADCB),

- Mashreq Bank (MB),

- Commercial Bank Dubai (CBD) and

- $\quad$ RAK Bank (RB).

\section{The Islamic banks are}

- Abu Dhabi Islamic Bank (ADIB),

- Dubai Islamic Bank (DIB),

- Noor Bank (NB) and

- Sharjah Islamic Bank (SIB)

- Al Hilal Bank (AHB) and

- Emirates Islamic Bank (EIB).

*First Abu Dhabi Bank (FAB) is the result of merger between First Gulf Bank (FGB) and National Bank of Abu Dhabi (NBAD). The financials for FAB were completely integrated in 2017. For the purpose of analysis from 2014 to 2016, the author has used individual banks (FGB and NBAD) financial statement extracted from the audited consolidated financial statements of NBAD and the audited consolidated financial statements of FGB as at 31 December 2014, 2015 and 2016.

The source of information is the published annual financial statement of the respective bank and publicly available stock market information. In addition, the analysis has also been done using public data available in S\&P Global Market Intelligence. The study is purely analytical and as previously mentioned, is based on secondary data. There are different financial ratios that have been used to calculate liquidity, asset quality, efficiency and leverage. The comparison of the conventional and Islamic banks is made to judge the performance using ratio analysis.

\begin{tabular}{|c|l|l|l|}
\hline \multicolumn{2}{|c|}{5.1 - Liquidity ratios } \\
\hline 1 & Net Loans to Deposits & Net Customer Loans/ Deposits & $\begin{array}{l}\text { "The loan-to-deposit ratio (LDR) is used to assess } \\
\text { a bank liquidity by comparing a bank's total } \\
\text { loans to its total deposits for the same period. If } \\
\text { the ratio is too high, it means that the bank may } \\
\text { not have enough liquidity to cover any unforeseen } \\
\text { fund requirements". }\end{array}$ \\
\hline 2 & $\begin{array}{l}\text { Advances to total } \\
\text { assets }\end{array}$ & Total net advances/ Total Assets & $\begin{array}{l}\text { "This ratio expresses the relationship of advances } \\
\text { (net) to total assets. This ratio is useful for banks } \\
\text { to find out to what an extent advance which is } \\
\text { core banking business comprises of total assets". }\end{array}$ \\
\hline 3 & Liquid Asset Ratio & Liquid Assets/ Total Assets & $\begin{array}{l}\text { "Liquid asset ratio refers to the proportion of } \\
\text { highly liquid assets held by banks to ensure their } \\
\text { ongoing ability to meet short-term obligations". }\end{array}$ \\
\hline
\end{tabular}

BIS [16] defines liquidity as "the ability of the bank to fund increases in assets and meet obligations as they come due, without incurring unacceptable losses". Liquidity risk arises from the fundamental role of banks in the maturity transformation of short-term deposits into long term loans. Liquidity ratios measure the proportion of liquid assets held by the bank to ensure ongoing ability to meet long-term and short term obligation. It is a financial metrics used to determine the ability to pay off obligations without raising any external funds.

Table-1: Net Loans to Deposit Ratio

\begin{tabular}{|l|c|c|c|c|c|}
\hline $\begin{array}{l}\text { Net Customer } \\
\text { Loans/ Deposits (\%) }\end{array}$ & $\mathbf{2 0 1 4}$ & $\mathbf{2 0 1 5}$ & $\mathbf{2 0 1 6}$ & $\mathbf{2 0 1 7}$ & $\mathbf{2 0 1 8}$ \\
\hline FAB & $98.89 \%$ & $105.13 \%$ & $105.04 \%$ & $83.48 \%$ & $75.87 \%$ \\
\hline ENBD & $95.24 \%$ & $94.20 \%$ & $93.45 \%$ & $93.13 \%$ & $94.27 \%$ \\
\hline ADCB & $11.55 \%$ & $101.90 \%$ & $101.94 \%$ & $100.12 \%$ & $94.21 \%$ \\
\hline Mashreq & $84.75 \%$ & $81.71 \%$ & $79.17 \%$ & $82.48 \%$ & $83.24 \%$ \\
\hline CBD & $98.94 \%$ & $96.41 \%$ & $95.86 \%$ & $97.65 \%$ & $95.82 \%$ \\
\hline RAK & $102.50 \%$ & $99.92 \%$ & $97.71 \%$ & $100.20 \%$ & $96.25 \%$ \\
\hline ADIB & $86.12 \%$ & $82.59 \%$ & $79.15 \%$ & $76.53 \%$ & $78.36 \%$ \\
\hline DIB & $80.11 \%$ & $88.40 \%$ & $93.95 \%$ & $90.59 \%$ & $92.99 \%$ \\
\hline Noor & $73.94 \%$ & $70.98 \%$ & $86.97 \%$ & $90.51 \%$ & $90.50 \%$ \\
\hline SIB & $99.20 \%$ & $96.44 \%$ & $93.25 \%$ & $97.26 \%$ & $91.25 \%$ \\
\hline AHB & $98.50 \%$ & $94.46 \%$ & $100.22 \%$ & $92.84 \%$ & $89.61 \%$ \\
\hline EIB & $83.00 \%$ & $86.97 \%$ & $88.36 \%$ & $80.90 \%$ & $86.93 \%$ \\
\hline
\end{tabular}




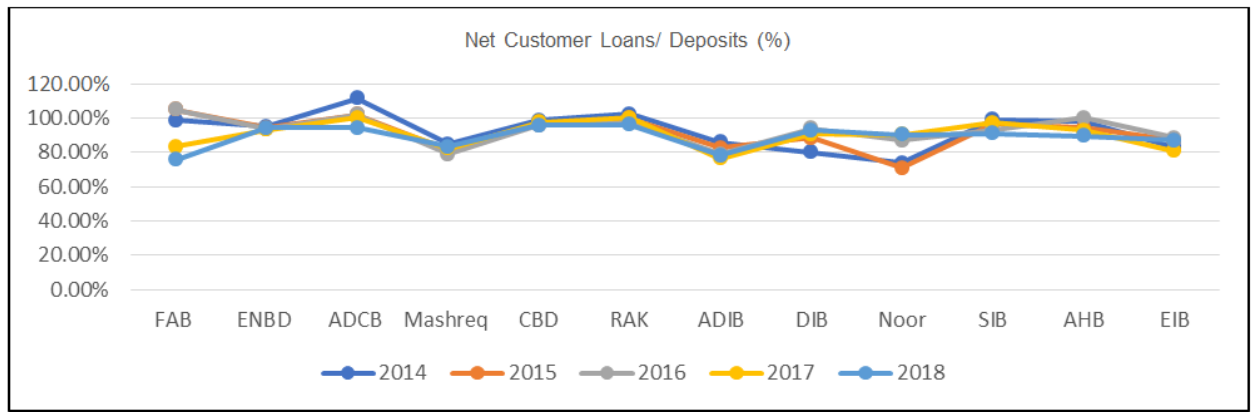

Fig-1: Graphical representation of Net Loans to Deposit Ratio for Conventional and Islamic Banks

Table-2: Advances to total assets

\begin{tabular}{|l|c|c|c|c|c|}
\hline $\begin{array}{l}\text { Advances to total assets = Total net } \\
\text { advances/ Total Assets (\%) }\end{array}$ & $\mathbf{2 0 1 4}$ & $\mathbf{2 0 1 5}$ & $\mathbf{2 0 1 6}$ & $\mathbf{2 0 1 7}$ & $\mathbf{2 0 1 8}$ \\
\hline FAB & $65.85 \%$ & $65.83 \%$ & $63.95 \%$ & $49.40 \%$ & $47.45 \%$ \\
\hline ENBD & $66.58 \%$ & $62.62 \%$ & $60.88 \%$ & $59.17 \%$ & $62.54 \%$ \\
\hline ADCB & $68.90 \%$ & $64.07 \%$ & $61.35 \%$ & $61.62 \%$ & $59.47 \%$ \\
\hline Mashreq & $54.90 \%$ & $52.32 \%$ & $49.74 \%$ & $50.21 \%$ & $49.57 \%$ \\
\hline CBD & $67.88 \%$ & $67.44 \%$ & $65.48 \%$ & $67.14 \%$ & $68.75 \%$ \\
\hline RAK & $72.54 \%$ & $68.49 \%$ & $67.57 \%$ & $66.42 \%$ & $62.39 \%$ \\
\hline ADIB & $65.24 \%$ & $66.23 \%$ & $63.96 \%$ & $62.08 \%$ & $62.84 \%$ \\
\hline DIB & $60.40 \%$ & $65.39 \%$ & $66.15 \%$ & $64.72 \%$ & $65.26 \%$ \\
\hline Noor & $62.17 \%$ & $58.80 \%$ & $63.85 \%$ & $64.33 \%$ & $63.09 \%$ \\
\hline SIB & $55.64 \%$ & $54.71 \%$ & $50.96 \%$ & $56.69 \%$ & $53.91 \%$ \\
\hline AHB & $74.30 \%$ & $70.48 \%$ & $74.29 \%$ & $69.74 \%$ & $64.31 \%$ \\
\hline EIB & $60.82 \%$ & $64.25 \%$ & $61.36 \%$ & $54.68 \%$ & $61.96 \%$ \\
\hline
\end{tabular}

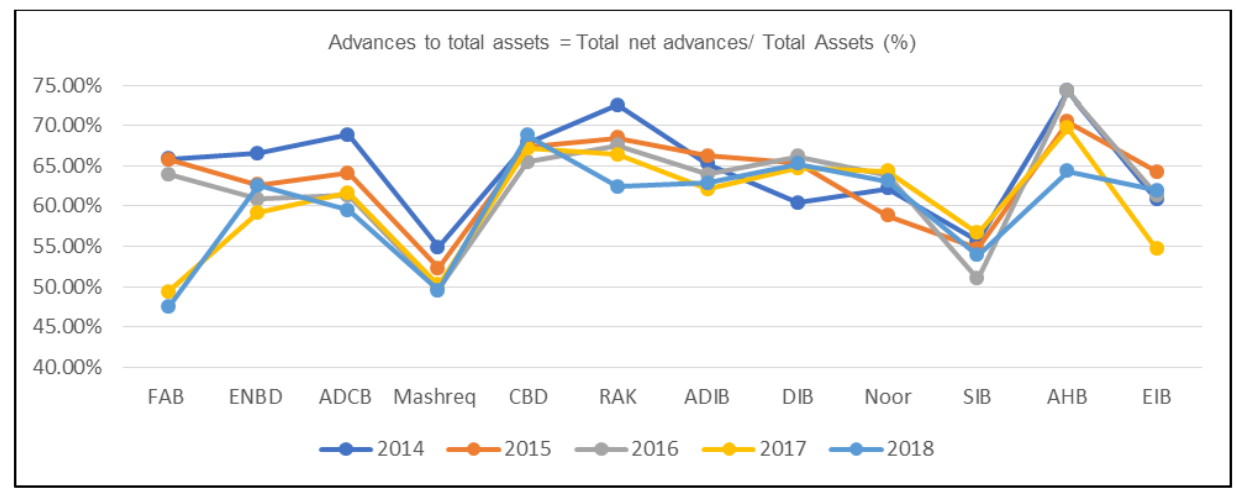

Fig-2: Graphical representation of Advances to total assets ratio for Conventional and Islamic Banks

Table-3: Liquid Asset Ratio

\begin{tabular}{|l|c|c|c|c|c|}
\hline Liquid Assets/ Assets (\%) & $\mathbf{2 0 1 4}$ & $\mathbf{2 0 1 5}$ & $\mathbf{2 0 1 6}$ & $\mathbf{2 0 1 7}$ & $\mathbf{2 0 1 8}$ \\
\hline FAB & $23.52 \%$ & $23.72 \%$ & $28.93 \%$ & $39.38 \%$ & $42.04 \%$ \\
\hline ENBD & $25.50 \%$ & $28.23 \%$ & $29.31 \%$ & $30.16 \%$ & $26.77 \%$ \\
\hline ADCB & $26.56 \%$ & $29.38 \%$ & $31.34 \%$ & $31.90 \%$ & $34.27 \%$ \\
\hline Mashreq & $31.80 \%$ & $34.07 \%$ & $33.00 \%$ & $31.24 \%$ & $32.47 \%$ \\
\hline CBD & $27.59 \%$ & $27.53 \%$ & $27.35 \%$ & $23.66 \%$ & $22.29 \%$ \\
\hline RAK & $14.04 \%$ & $21.79 \%$ & $34.11 \%$ & $29.11 \%$ & $23.21 \%$ \\
\hline ADIB & $23.27 \%$ & $20.97 \%$ & $22.23 \%$ & $22.62 \%$ & $20.66 \%$ \\
\hline DIB & $18.38 \%$ & $13.73 \%$ & $13.33 \%$ & $16.76 \%$ & $14.77 \%$ \\
\hline Noor & $29.50 \%$ & $34.84 \%$ & $29.96 \%$ & $29.40 \%$ & $29.58 \%$ \\
\hline SIB & $38.40 \%$ & $40.63 \%$ & $40.58 \%$ & $21.42 \%$ & $26.94 \%$ \\
\hline AHB & $17.79 \%$ & $15.19 \%$ & $11.86 \%$ & $17.29 \%$ & $24.15 \%$ \\
\hline EIB & $49.80 \%$ & $45.24 \%$ & $48.02 \%$ & $42.40 \%$ & $34.99 \%$ \\
\hline
\end{tabular}




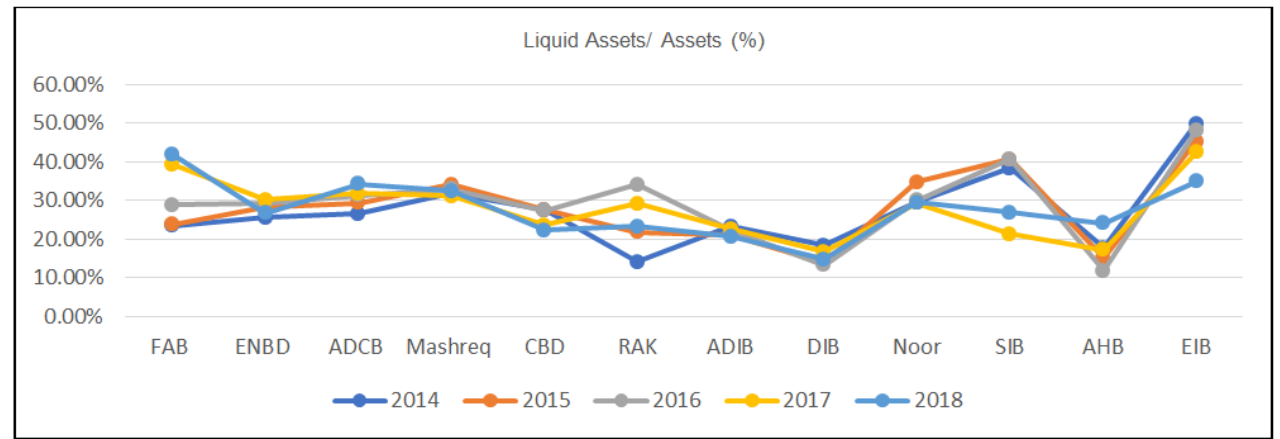

Fig-3: Graphical representation of Liquid assets ratio for Conventional and Islamic Banks

\begin{tabular}{|c|c|c|c|}
\hline \multicolumn{4}{|c|}{5.2 - Efficiency Ratios } \\
\hline 4 & $\begin{array}{l}\text { Return on Average } \\
\text { Assets (ROAA) }\end{array}$ & Net profit after tax/ total assets & $\begin{array}{l}\text { "This ratio expresses the capacity of earning } \\
\text { profit by a bank on its total assets employed in the } \\
\text { business. It is calculated as percentage of net } \\
\text { profit after tax to total assets. It is useful for } \\
\text { measuring efficiency as it shows to what extent } \\
\text { assets are generating profits". }\end{array}$ \\
\hline 5 & $\begin{array}{l}\text { Return on Average } \\
\text { Equity (ROAE) }\end{array}$ & $\begin{array}{l}\text { Net profit after tax (NPAT)/ } \\
\text { shareholders' equity }\end{array}$ & $\begin{array}{l}\text { "This ratio expresses the return on shareholders' } \\
\text { equity. ROAE is a direct measure of returns to the } \\
\text { shareholders. It is calculated as a percentage of } \\
\text { the net profit after tax to total Shareholders" } \\
\text { equity". }\end{array}$ \\
\hline 6 & $\begin{array}{l}\text { Earnings per share } \\
\text { (EPS) }\end{array}$ & $\begin{array}{l}\text { Net profit after tax/no of } \\
\text { ordinary shares }\end{array}$ & $\begin{array}{l}\text { "EPS is the ratio between net profit after tax to } \\
\text { number of shares outstanding at the end of the } \\
\text { year as shown in balance sheet and its relevant } \\
\text { notes to accounts. It is useful for whole financial } \\
\text { sector except for Mudarbaha companies where } \\
\text { certificates are issued for raising capital". }\end{array}$ \\
\hline 7 & Net Interest Margin & $\begin{array}{l}\text { (Net return on investment - } \\
\text { Interest paid) / Average Assets }\end{array}$ & $\begin{array}{l}\text { "Net interest margin (NIM) is a measure of the } \\
\text { difference between the interest income generated } \\
\text { by banks or other financial institutions and the } \\
\text { amount of interest paid out to their lenders (for } \\
\text { example, deposits), relative to the amount of their } \\
\text { (interest-earning) assets". }\end{array}$ \\
\hline 8 & Cost to income & $\begin{array}{l}\text { operating cost/ operating } \\
\text { income }\end{array}$ & $\begin{array}{l}\text { "Cost-to-income ratio is calculated by dividing } \\
\text { the operating expenses by the operating income } \\
\text { generated i.e.net interest income plus the other } \\
\text { income. Cost-to-income ratio is important for } \\
\text { determining the profitability of a bank". }\end{array}$ \\
\hline
\end{tabular}

There is no single scientific way to measure efficiency of the banks. Wozniewska G. [17] emphasized that it is difficult to measure efficiency of the bank as there is no standard to define the output of the bank. Unlike manufacturing industry, where production can be measured; it is difficult in banking to measure productivity output. Neither the number of accounts nor total assets, total loans, nor total deposits provides a good index of output. Moreover, the value added of banks - given by their labor costs and profits - measures both the output and cost of banking. While many researchers use accounting and financial data on net interest margin, interest/ non-interest costs and profit after tax as measures for bank efficiency, the usefulness of such data is undermined by substantial structural and accounting differences across countries, among individual banks and over time. The author has used ROAA, ROAE, EPS, NIM and Cost to Income to measure efficiency of the bank 
Manoj Kapur; Saudi J Bus Manag Stud, Jan., 2020; 5(1): 50-63

Table-4: Return on Average Assets (ROAA)

\begin{tabular}{|l|c|c|c|c|c|}
\hline ROAA (\%) & $\mathbf{2 0 1 4}$ & $\mathbf{2 0 1 5}$ & $\mathbf{2 0 1 6}$ & $\mathbf{2 0 1 7}$ & $\mathbf{2 0 1 8}$ \\
\hline FAB & $2.84 \%$ & $2.73 \%$ & $2.63 \%$ & $1.86 \%$ & $1.72 \%$ \\
\hline ENBD & $1.47 \%$ & $1.86 \%$ & $1.69 \%$ & $1.83 \%$ & $2.08 \%$ \\
\hline ADCB & $2.17 \%$ & $2.32 \%$ & $1.71 \%$ & $1.64 \%$ & $1.79 \%$ \\
\hline Mashreq & $2.50 \%$ & $2.21 \%$ & $1.67 \%$ & $1.70 \%$ & $1.59 \%$ \\
\hline CBD & $2.64 \%$ & $2.07 \%$ & $1.65 \%$ & $1.48 \%$ & $1.64 \%$ \\
\hline RAK & $4.36 \%$ & $3.61 \%$ & $1.62 \%$ & $1.82 \%$ & $1.81 \%$ \\
\hline ADIB & $1.64 \%$ & $1.68 \%$ & $1.62 \%$ & $1.88 \%$ & $2.02 \%$ \\
\hline DIB & $2.28 \%$ & $2.69 \%$ & $2.41 \%$ & $2.33 \%$ & $2.31 \%$ \\
\hline Noor & $2.60 \%$ & $1.45 \%$ & $0.92 \%$ & $0.89 \%$ & $1.29 \%$ \\
\hline SIB & $1.61 \%$ & $1.47 \%$ & $1.50 \%$ & $1.32 \%$ & $1.20 \%$ \\
\hline AHB & $0.21 \%$ & $0.25 \%$ & $0.29 \%$ & $0.32 \%$ & $0.24 \%$ \\
\hline EIB & $0.88 \%$ & $1.34 \%$ & $0.18 \%$ & $1.17 \%$ & $1.56 \%$ \\
\hline
\end{tabular}

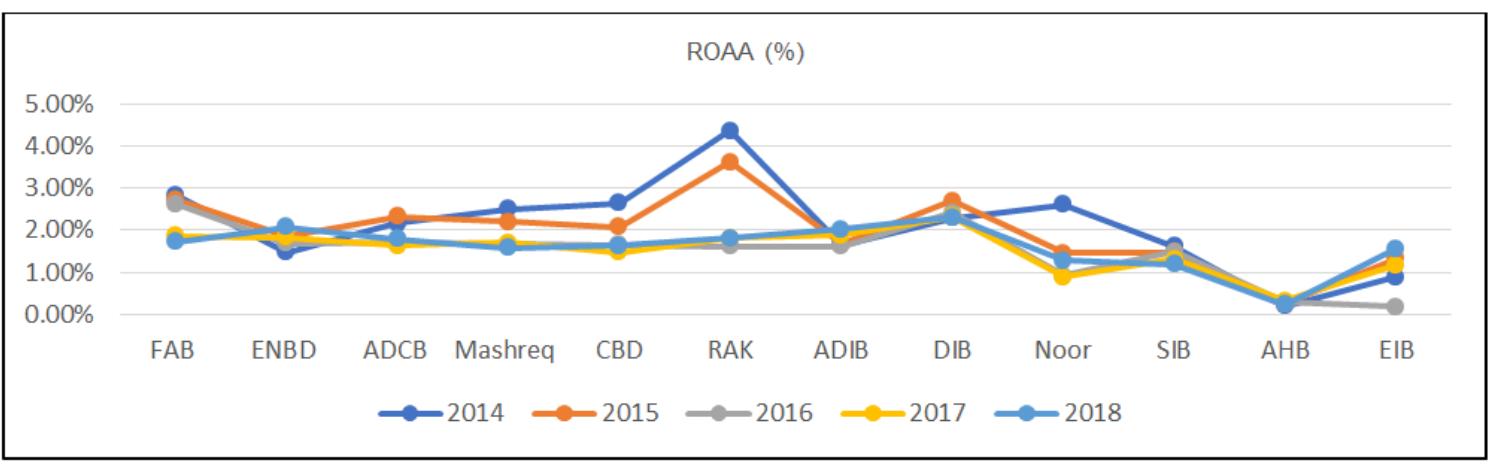

Fig-4: Graphical representation of Return on Average Asset ratio for Conventional and Islamic Banks

Table-5: Return on Average Equity (ROAE)

\begin{tabular}{|l|c|c|c|c|c|}
\hline ROAE (\%) & $\mathbf{2 0 1 4}$ & $\mathbf{2 0 1 5}$ & $\mathbf{2 0 1 6}$ & $\mathbf{2 0 1 7}$ & $\mathbf{2 0 1 8}$ \\
\hline FAB & $17.84 \%$ & $17.69 \%$ & $17.19 \%$ & $12.19 \%$ & $12.26 \%$ \\
\hline ENBD & $11.74 \%$ & $14.87 \%$ & $14.01 \%$ & $14.98 \%$ & $16.70 \%$ \\
\hline ADCB & $16.87 \%$ & $18.36 \%$ & $14.46 \%$ & $13.91 \%$ & $15.53 \%$ \\
\hline Mashreq & $15.78 \%$ & $13.91 \%$ & $10.38 \%$ & $10.44 \%$ & $10.18 \%$ \\
\hline CBD & $16.45 \%$ & $13.53 \%$ & $12.16 \%$ & $11.63 \%$ & $13.27 \%$ \\
\hline RAK & $22.41 \%$ & $19.15 \%$ & $8.65 \%$ & $10.59 \%$ & $13.27 \%$ \\
\hline ADIB & $13.35 \%$ & $13.60 \%$ & $12.72 \%$ & $14.43 \%$ & $15.15 \%$ \\
\hline DIB & $16.78 \%$ & $18.24 \%$ & $16.33 \%$ & $16.54 \%$ & $16.22 \%$ \\
\hline Noor & $16.00 \%$ & $16.53 \%$ & $8.28 \%$ & $6.62 \%$ & $10.14 \%$ \\
\hline SIB & $8.38 \%$ & $8.93 \%$ & $9.78 \%$ & $9.31 \%$ & $9.67 \%$ \\
\hline AHB & $1.74 \%$ & $1.91 \%$ & $2.28 \%$ & $2.55 \%$ & $1.92 \%$ \\
\hline EIB & $8.37 \%$ & $13.15 \%$ & $1.96 \%$ & $9.98 \%$ & $13.37 \%$ \\
\hline
\end{tabular}

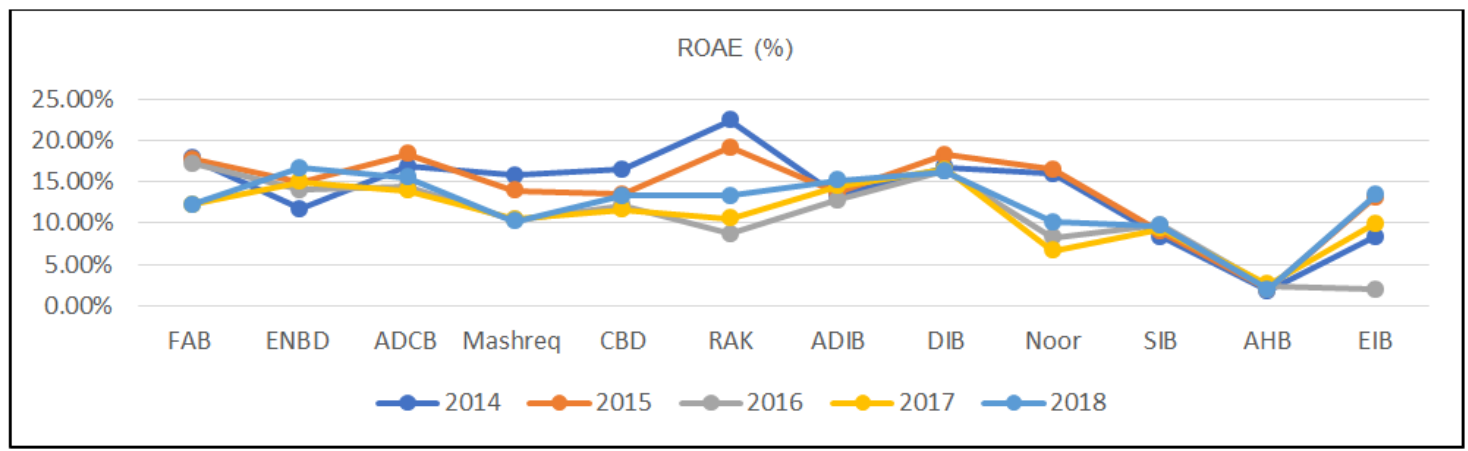

Fig-5: Graphical representation of Return on Average Equity ratio for Conventional and Islamic Banks 
Manoj Kapur; Saudi J Bus Manag Stud, Jan., 2020; 5(1): 50-63

Table-6: Earnings per share (EPS)

\begin{tabular}{|l|c|c|c|c|c|}
\hline Basic EPS (Dhs.) & $\mathbf{2 0 1 4}$ & $\mathbf{2 0 1 5}$ & $\mathbf{2 0 1 6}$ & $\mathbf{2 0 1 7}$ & $\mathbf{2 0 1 8}$ \\
\hline FAB & 1.22 & 1.32 & 1.32 & 0.91 & 1.06 \\
\hline ENBD & 0.83 & 1.18 & 1.20 & 1.40 & 1.70 \\
\hline ADCB & 0.74 & 0.93 & 0.77 & 0.80 & 0.90 \\
\hline Mashreq & 13.53 & 13.53 & 10.85 & 11.56 & 11.60 \\
\hline CBD & 0.43 & 0.38 & 0.36 & 0.36 & 0.41 \\
\hline RAK & 0.87 & 0.84 & 0.39 & 0.48 & 0.54 \\
\hline ADIB & 0.43 & 0.50 & 0.49 & 0.59 & 0.64 \\
\hline DIB & 0.56 & 0.74 & 0.67 & 0.69 & 0.72 \\
\hline Noor & - & - & - & - & - \\
\hline SIB & 0.15 & 0.15 & 0.17 & 0.18 & 0.17 \\
\hline AHB & 0.03 & 0.03 & 0.04 & - & - \\
\hline EIB & 0.08 & 0.15 & 0.02 & 0.13 & 0.17 \\
\hline
\end{tabular}

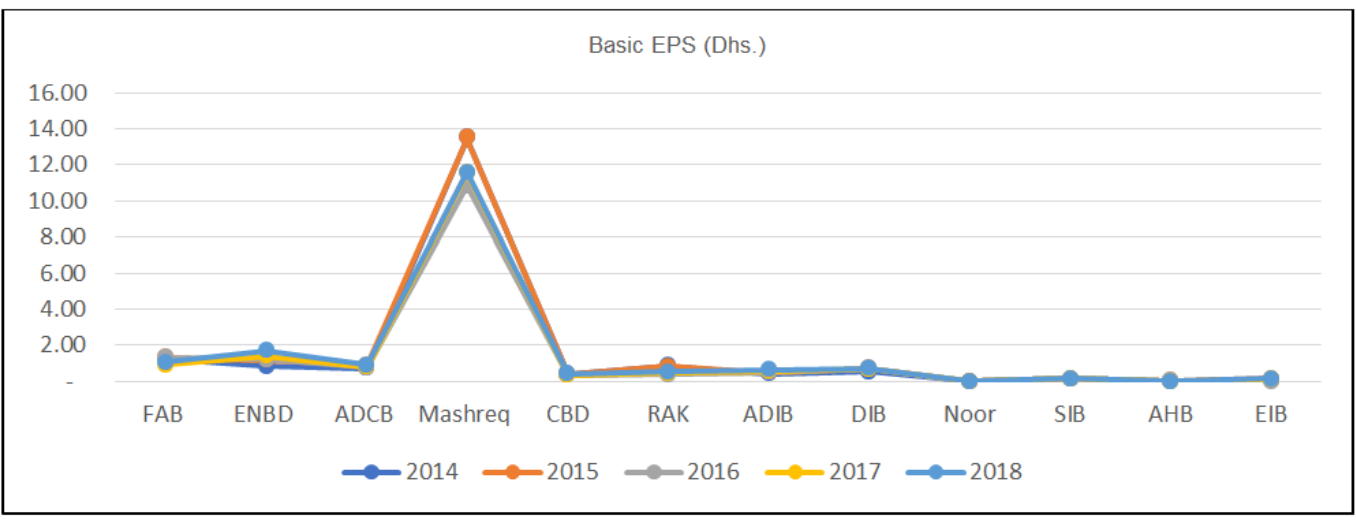

Fig-6: Graphical representation of Earning per Share (Dirhams) for Conventional and Islamic Banks

Table-7: Net Interest Margin

\begin{tabular}{|l|c|c|c|c|c|}
\hline Net Interest Margin (\%) & $\mathbf{2 0 1 4}$ & $\mathbf{2 0 1 5}$ & $\mathbf{2 0 1 6}$ & $\mathbf{2 0 1 7}$ & $\mathbf{2 0 1 8}$ \\
\hline FAB & $3.51 \%$ & $3.18 \%$ & $2.98 \%$ & $2.48 \%$ & $2.00 \%$ \\
\hline ENBD & $2.92 \%$ & $2.84 \%$ & $2.50 \%$ & $2.49 \%$ & $2.81 \%$ \\
\hline ADCB & $2.97 \%$ & $3.02 \%$ & $2.71 \%$ & $2.71 \%$ & $2.81 \%$ \\
\hline Mashreq & $3.29 \%$ & $3.18 \%$ & $3.10 \%$ & $3.19 \%$ & $3.08 \%$ \\
\hline CBD & $3.65 \%$ & $3.34 \%$ & $3.02 \%$ & $2.91 \%$ & $2.97 \%$ \\
\hline RAK & $0.00 \%$ & $0.00 \%$ & $0.00 \%$ & $5.58 \%$ & $5.76 \%$ \\
\hline ADIB & $3.75 \%$ & $3.77 \%$ & $3.81 \%$ & $3.71 \%$ & $3.82 \%$ \\
\hline DIB & $3.26 \%$ & $3.40 \%$ & $2.99 \%$ & $2.95 \%$ & $2.95 \%$ \\
\hline Noor & $2.66 \%$ & $2.73 \%$ & $2.62 \%$ & $2.89 \%$ & $2.77 \%$ \\
\hline SIB & $0.00 \%$ & $0.00 \%$ & $0.00 \%$ & $1.63 \%$ & $1.57 \%$ \\
\hline AHB & $0.00 \%$ & $0.00 \%$ & $0.00 \%$ & $2.46 \%$ & $2.28 \%$ \\
\hline EIB & $0.00 \%$ & $0.00 \%$ & $0.00 \%$ & $2.11 \%$ & $2.90 \%$ \\
\hline
\end{tabular}

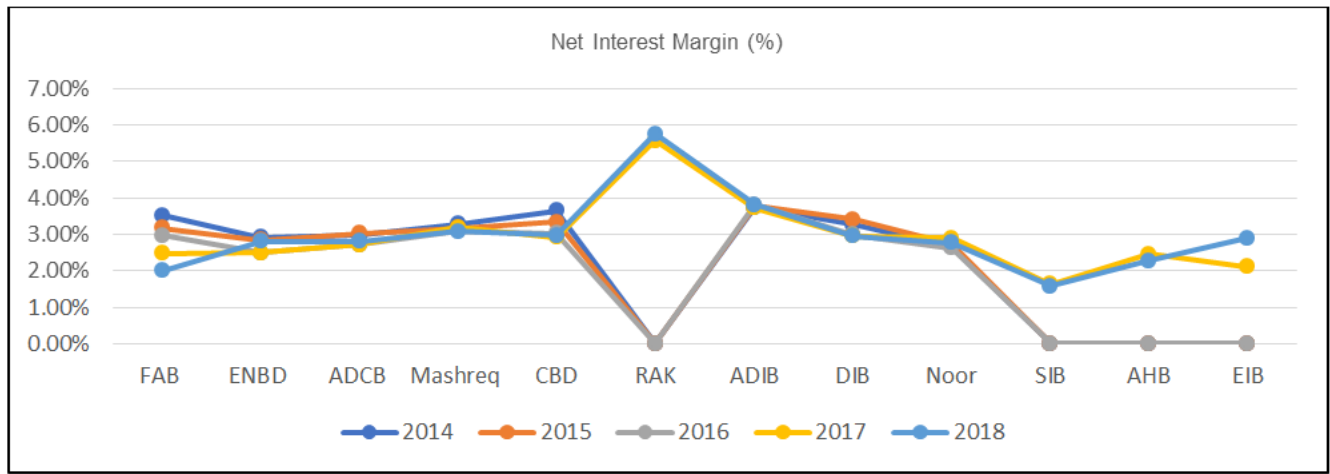

Fig-7: Graphical representation of Net Interest Margin ratio for Conventional and Islamic Banks 
Manoj Kapur; Saudi J Bus Manag Stud, Jan., 2020; 5(1): 50-63

Table-8: Cost to income

\begin{tabular}{|l|c|c|c|c|c|}
\hline Cost-to-Income (\%) & $\mathbf{2 0 1 4}$ & $\mathbf{2 0 1 5}$ & $\mathbf{2 0 1 6}$ & $\mathbf{2 0 1 7}$ & $\mathbf{2 0 1 8}$ \\
\hline FAB & $20.68 \%$ & $20.68 \%$ & $20.85 \%$ & $27.04 \%$ & $25.89 \%$ \\
\hline ENBD & $29.95 \%$ & $30.66 \%$ & $32.84 \%$ & $31.20 \%$ & $32.04 \%$ \\
\hline ADCB & $34.04 \%$ & $34.22 \%$ & $32.88 \%$ & $33.10 \%$ & $33.55 \%$ \\
\hline Mashreq & $37.80 \%$ & $41.36 \%$ & $39.02 \%$ & $39.24 \%$ & $44.09 \%$ \\
\hline CBD & $33.67 \%$ & $36.51 \%$ & $35.36 \%$ & $34.08 \%$ & $31.50 \%$ \\
\hline RAK & $42.34 \%$ & $37.53 \%$ & $35.65 \%$ & $37.96 \%$ & $38.85 \%$ \\
\hline ADIB & $45.19 \%$ & $46.24 \%$ & $45.45 \%$ & $44.72 \%$ & $45.82 \%$ \\
\hline DIB & $36.09 \%$ & $34.26 \%$ & $33.98 \%$ & $30.38 \%$ & $28.31 \%$ \\
\hline Noor & $48.27 \%$ & $45.68 \%$ & $40.49 \%$ & $37.57 \%$ & $37.42 \%$ \\
\hline SIB & $40.69 \%$ & $37.61 \%$ & $41.21 \%$ & $46.78 \%$ & $52.89 \%$ \\
\hline AHB & $48.42 \%$ & $54.09 \%$ & $61.77 \%$ & $57.23 \%$ & $57.40 \%$ \\
\hline EIB & $40.72 \%$ & $40.36 \%$ & $43.72 \%$ & $42.20 \%$ & $46.81 \%$ \\
\hline
\end{tabular}

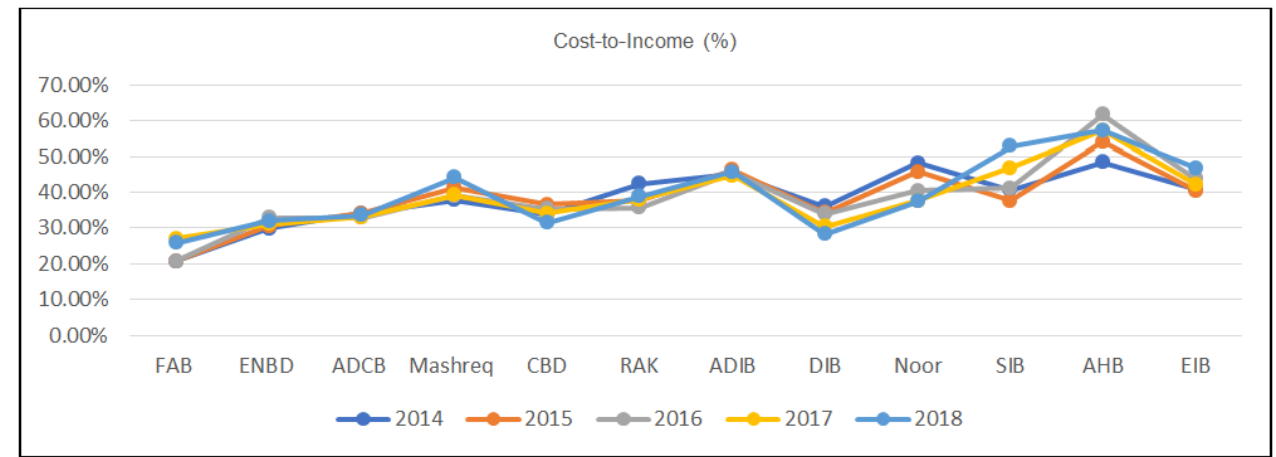

Fig-8: Graphical representation of Cost to Income ratio for Conventional and Islamic Banks

\begin{tabular}{|r|l|l|l|}
\hline \multicolumn{2}{|c|}{$\mathbf{5 . 3}$ - Asset Quality } \\
\hline 9 & $\begin{array}{l}\text { Non-performing } \\
\text { loans (NPL) to gross } \\
\text { advances }\end{array}$ & NPL/gross advances & $\begin{array}{l}\text { "This ratio expresses the quality of loan portfolio of a bank. It shows } \\
\text { the percentage of NPLs as gross advances made by a bank and } \\
\text { evaluates assets quality based on loan portfolio. This ratio is useful for } \\
\text { banks and DFIs". }\end{array}$ \\
\hline 10 & $\begin{array}{l}\text { Equity-To-Asset } \\
\text { ratio }\end{array}$ & $\begin{array}{l}\text { Total Equity/ Total } \\
\text { Assets }\end{array}$ & $\begin{array}{l}\text { "The formula is arrived by dividing the Net Worth by the Total } \\
\text { Assets. This ratio is measured as a percentage. The higher the } \\
\text { percentage the less is leverage through debt". }\end{array}$ \\
\hline 11 & $\begin{array}{l}\text { Provision Coverage } \\
\text { Ratio }\end{array}$ & $\begin{array}{l}\text { Provisions/ Average } \\
\text { Amortized Loans (\%) }\end{array}$ & "The ratio measures the provisioning coverage for bad loans". \\
\hline
\end{tabular}

Abata, M. A. [18] defined asset quality as an aspect of banks management which entails the evaluation of a firm asset in order to facilitate the measurement of the level and size of credit risk associated with its operation. It is the left side of a bank's balance sheet and focused on the quality of loans which provides earnings for a bank. Asset quality and loan quality are two terms with basically mean the same. Its management is considered extremely important by the banking sector. Again, there are several ways to measure quality of banks' asset. The author has chosen to use NPL, provision coverage and Equity to asset ratio.

Table-9: Non-performing loans (NPL) to gross advances

\begin{tabular}{|l|c|c|c|c|c|}
\hline Problem Loans/ Gross Customer Loans (\%) & $\mathbf{2 0 1 4}$ & $\mathbf{2 0 1 5}$ & $\mathbf{2 0 1 6}$ & $\mathbf{2 0 1 7}$ & $\mathbf{2 0 1 8}$ \\
\hline FAB & $8.79 \%$ & $2.78 \%$ & $2.29 \%$ & $3.09 \%$ & $3.15 \%$ \\
\hline ENBD & $7.91 \%$ & $7.09 \%$ & $6.44 \%$ & $6.17 \%$ & $5.92 \%$ \\
\hline ADCB & $3.13 \%$ & $3.17 \%$ & $2.80 \%$ & $2.18 \%$ & $3.00 \%$ \\
\hline Mashreq & $4.48 \%$ & $3.21 \%$ & $3.56 \%$ & $3.39 \%$ & $3.82 \%$ \\
\hline CBD & $9.43 \%$ & $7.01 \%$ & $6.96 \%$ & $6.61 \%$ & $7.12 \%$ \\
\hline RAK & $2.40 \%$ & $3.20 \%$ & $4.20 \%$ & $4.01 \%$ & $4.24 \%$ \\
\hline ADIB & $4.37 \%$ & $3.85 \%$ & $4.54 \%$ & $5.39 \%$ & $4.84 \%$ \\
\hline DIB & $8.28 \%$ & $5.14 \%$ & $3.93 \%$ & $3.48 \%$ & $3.47 \%$ \\
\hline Noor & $7.32 \%$ & $4.71 \%$ & $5.14 \%$ & $4.34 \%$ & $4.43 \%$ \\
\hline SIB & $6.00 \%$ & $3.50 \%$ & $4.00 \%$ & $4.96 \%$ & $5.48 \%$ \\
\hline AHB & $7.00 \%$ & $8.46 \%$ & $8.35 \%$ & $8.68 \%$ & $8.46 \%$ \\
\hline EIB & $10.25 \%$ & $8.83 \%$ & $9.06 \%$ & $10.28 \%$ & $8.23 \%$ \\
\hline
\end{tabular}




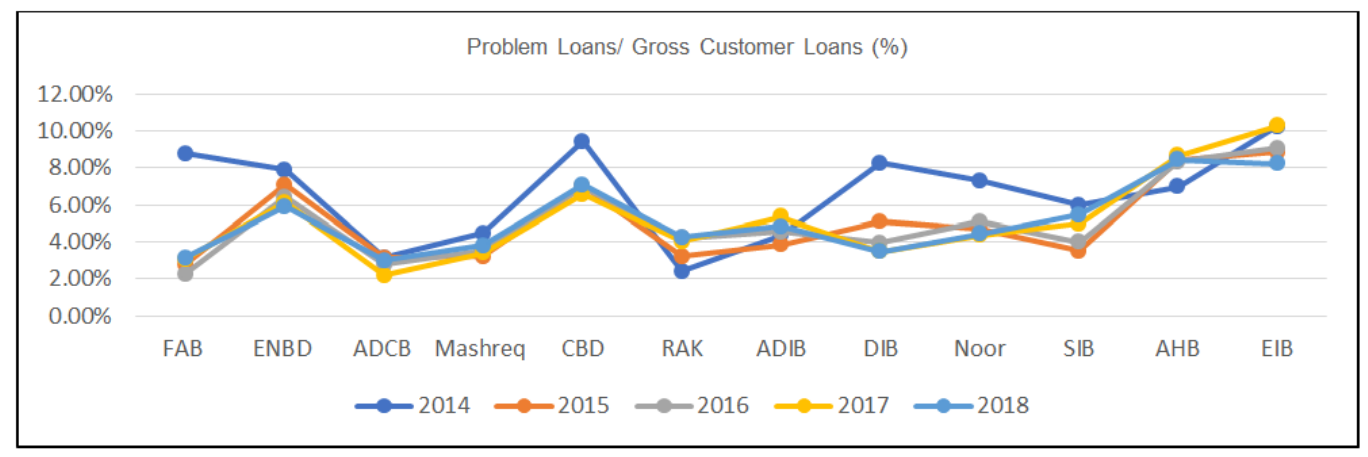

Fig-9: Graphical representation of Non-Performing Loans ratio for Conventional and Islamic Banks

Table-10: Equity-To-Asset ratio

\begin{tabular}{|l|c|c|c|c|c|}
\hline Total Equity/ Total Assets (\%) & $\mathbf{2 0 1 4}$ & $\mathbf{2 0 1 5}$ & $\mathbf{2 0 1 6}$ & $\mathbf{2 0 1 7}$ & $\mathbf{2 0 1 8}$ \\
\hline FAB & $16.37 \%$ & $15.96 \%$ & $15.36 \%$ & $15.28 \%$ & $13.71 \%$ \\
\hline ENBD & $12.88 \%$ & $12.48 \%$ & $12.02 \%$ & $12.62 \%$ & $12.80 \%$ \\
\hline ADCB & $12.95 \%$ & $12.59 \%$ & $11.75 \%$ & $12.24 \%$ & $11.72 \%$ \\
\hline Mashreq & $15.98 \%$ & $16.05 \%$ & $15.87 \%$ & $16.88 \%$ & $14.84 \%$ \\
\hline CBD & $16.66 \%$ & $14.22 \%$ & $13.55 \%$ & $12.90 \%$ & $12.44 \%$ \\
\hline RAK & $20.47 \%$ & $19.01 \%$ & $17.83 \%$ & $16.21 \%$ & $13.53 \%$ \\
\hline ADIB & $12.23 \%$ & $12.73 \%$ & $12.64 \%$ & $13.44 \%$ & $14.17 \%$ \\
\hline DIB & $14.29 \%$ & $15.21 \%$ & $15.59 \%$ & $13.93 \%$ & $15.26 \%$ \\
\hline Noor & $11.28 \%$ & $8.90 \%$ & $13.18 \%$ & $13.71 \%$ & $11.85 \%$ \\
\hline SIB & $17.64 \%$ & $15.74 \%$ & $14.48 \%$ & $14.41 \%$ & $12.04 \%$ \\
\hline AHB & $13.50 \%$ & $12.67 \%$ & $12.65 \%$ & $12.33 \%$ & $12.58 \%$ \\
\hline EIB & $10.49 \%$ & $9.58 \%$ & $11.29 \%$ & $11.81 \%$ & $12.35 \%$ \\
\hline
\end{tabular}

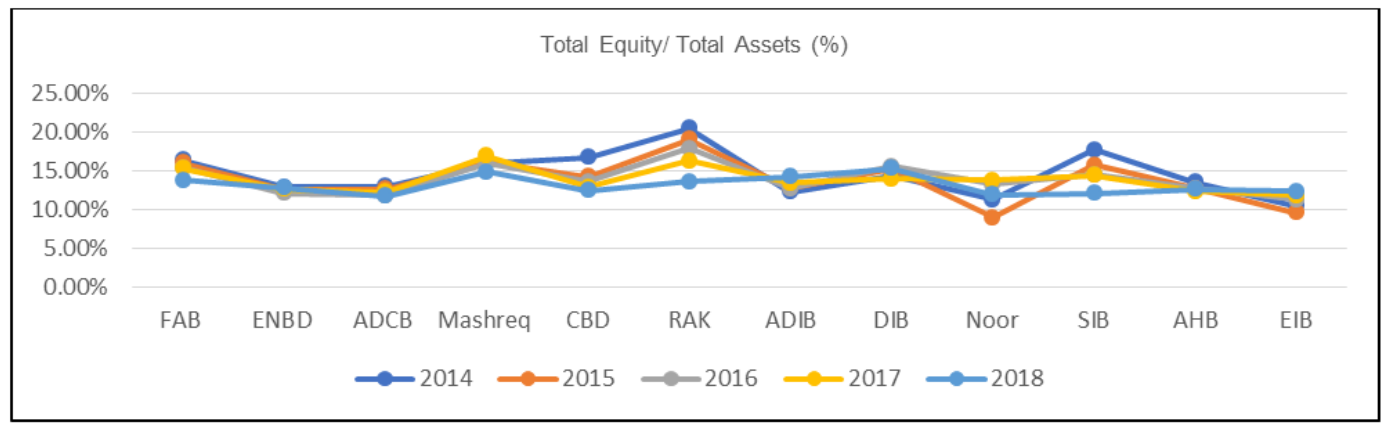

Fig-10: Graphical representation of Equity to Asset ratio for Conventional and Islamic Banks

Table-11: Provision Coverage Ratio

\begin{tabular}{|l|c|c|c|c|c|}
\hline Provisions/ Average Loans (\%) & $\mathbf{2 0 1 4}$ & $\mathbf{2 0 1 5}$ & $\mathbf{2 0 1 6}$ & $\mathbf{2 0 1 7}$ & $\mathbf{2 0 1 8}$ \\
\hline FAB & $1.05 \%$ & $0.95 \%$ & $0.94 \%$ & $0.86 \%$ & $0.49 \%$ \\
\hline ENBD & $1.95 \%$ & $1.29 \%$ & $0.88 \%$ & $0.72 \%$ & $0.53 \%$ \\
\hline ADCB & $0.60 \%$ & $0.34 \%$ & $0.99 \%$ & $1.03 \%$ & $0.78 \%$ \\
\hline Mashreq & $1.93 \%$ & $1.71 \%$ & $2.76 \%$ & $2.31 \%$ & $1.74 \%$ \\
\hline CBD & $0.92 \%$ & $1.14 \%$ & $1.41 \%$ & $1.51 \%$ & $1.41 \%$ \\
\hline RAK & $2.53 \%$ & $3.92 \%$ & $6.43 \%$ & $5.09 \%$ & $4.28 \%$ \\
\hline ADIB & $0.93 \%$ & $1.05 \%$ & $1.23 \%$ & $0.99 \%$ & $0.74 \%$ \\
\hline DIB & $0.85 \%$ & $0.56 \%$ & $0.90 \%$ & $0.66 \%$ & $0.66 \%$ \\
\hline Noor & $0.76 \%$ & $0.96 \%$ & $2.63 \%$ & $3.14 \%$ & $2.05 \%$ \\
\hline SIB & $1.69 \%$ & $2.20 \%$ & $1.21 \%$ & $0.81 \%$ & $0.20 \%$ \\
\hline AHB & $2.53 \%$ & $1.89 \%$ & $1.28 \%$ & $1.15 \%$ & $1.35 \%$ \\
\hline EIB & $2.56 \%$ & $2.44 \%$ & $3.25 \%$ & $1.82 \%$ & $0.84 \%$ \\
\hline
\end{tabular}




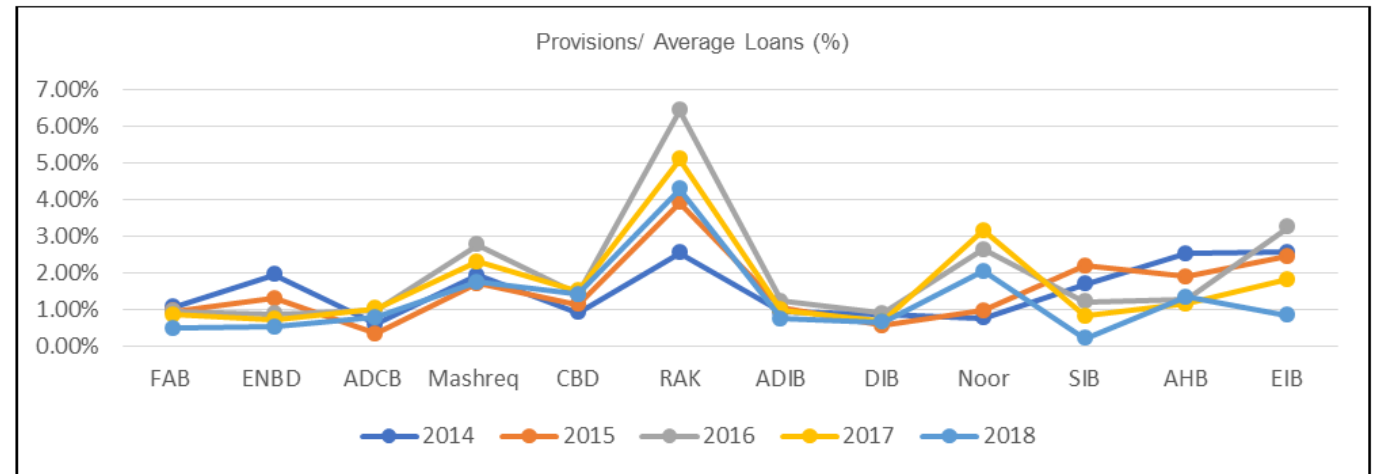

Fig-11: Graphical representation of Provision coverage ratio for Conventional and Islamic Banks

\begin{tabular}{|c|l|l|l|}
\hline \multicolumn{2}{|c|}{5.4 - Leverage Ratio } \\
\hline 12 & Capital ratio & $\begin{array}{l}\text { Total share holders" } \\
\text { equity/total asset }\end{array}$ & $\begin{array}{l}\text { "The ratio between shareholders equity and total assets } \\
\text { expressed as the percentage of equity to total assets". }\end{array}$ \\
\hline 13 & Debt to equity ratio & Total Debt/ Total Equity & $\begin{array}{l}\text { "The D/E ratio is calculated as total liabilities divided by } \\
\text { total shareholders' equity. A higher debt to equity ratio } \\
\text { indicates that more creditor financing (bank loans) is used } \\
\text { than investor financing (shareholders)". }\end{array}$ \\
\hline
\end{tabular}

Leverage allows a financial institution to increase the potential gains or losses on a position or investment beyond what would be possible through a direct investment of its own funds. According to D'Hulster, K. [19], while excessive leverage would be the reason for global financial crises however there is no single tool or measure that could have avoided the crises. The leverage ratio is a prudential tool that can be implemented without any risk sensitive capital requirement. The author has chosen to use capital and debt to equity as a measure for leverage.

Table-12: Capital ratio

\begin{tabular}{|l|c|c|c|c|c|}
\hline Total Capital Ratio (\%) & $\mathbf{2 0 1 4}$ & $\mathbf{2 0 1 5}$ & $\mathbf{2 0 1 6}$ & $\mathbf{2 0 1 7}$ & $\mathbf{2 0 1 8}$ \\
\hline FAB & $17.49 \%$ & $17.51 \%$ & $18.33 \%$ & $16.27 \%$ & $15.72 \%$ \\
\hline ENBD & $21.06 \%$ & $20.74 \%$ & $21.22 \%$ & $21.16 \%$ & $20.93 \%$ \\
\hline ADCB & $21.03 \%$ & $19.76 \%$ & $18.92 \%$ & $19.09 \%$ & $17.26 \%$ \\
\hline Mashreq & $16.62 \%$ & $16.90 \%$ & $16.86 \%$ & $17.16 \%$ & $16.45 \%$ \\
\hline CBD & $18.08 \%$ & $16.59 \%$ & $15.75 \%$ & $15.15 \%$ & $14.56 \%$ \\
\hline RAK & $26.51 \%$ & $22.27 \%$ & $21.80 \%$ & $20.69 \%$ & $17.19 \%$ \\
\hline ADIB & $14.36 \%$ & $15.14 \%$ & $15.25 \%$ & $16.09 \%$ & $17.18 \%$ \\
\hline DIB & $14.87 \%$ & $15.74 \%$ & $18.12 \%$ & $15.30 \%$ & $17.46 \%$ \\
\hline Noor & $18.10 \%$ & $15.19 \%$ & $17.25 \%$ & $17.90 \%$ & $16.16 \%$ \\
\hline SIB & $23.92 \%$ & $21.89 \%$ & $21.35 \%$ & $20.60 \%$ & $16.96 \%$ \\
\hline AHB & $17.03 \%$ & $15.96 \%$ & $15.19 \%$ & $16.09 \%$ & $17.32 \%$ \\
\hline EIB & $13.83 \%$ & $13.22 \%$ & $16.05 \%$ & $17.36 \%$ & $18.19 \%$ \\
\hline
\end{tabular}

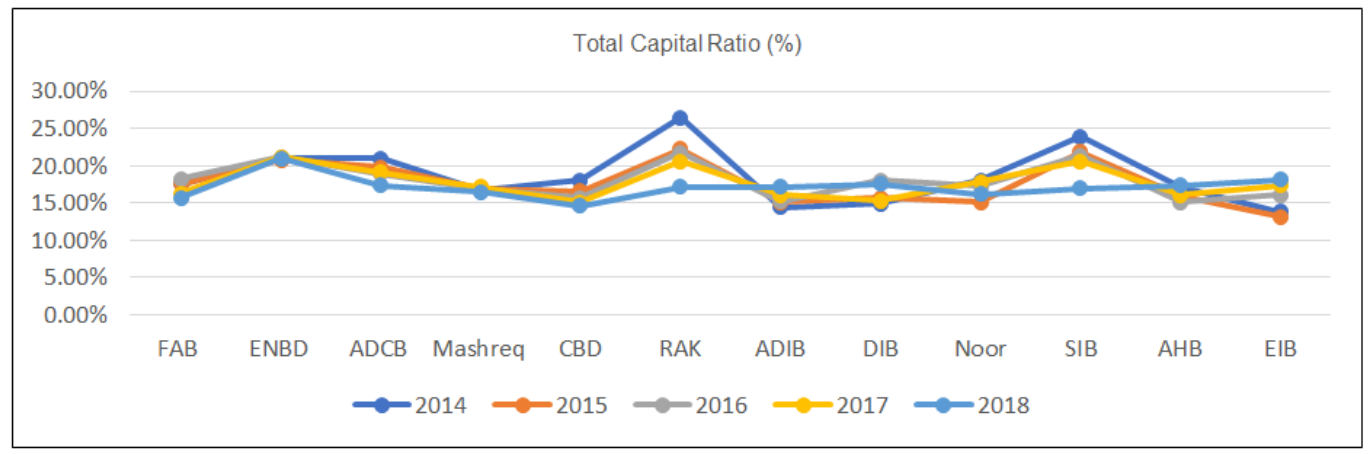

Fig-12: Graphical representation of Total Capital ratio for Conventional and Islamic Banks 
Table-13: Debt to equity ratio

\begin{tabular}{|l|c|c|c|c|c|}
\hline Total Debt/ Total Equity (x) & $\mathbf{2 0 1 4}$ & $\mathbf{2 0 1 5}$ & $\mathbf{2 0 1 6}$ & $\mathbf{2 0 1 7}$ & $\mathbf{2 0 1 8}$ \\
\hline FAB & 0.46 & 0.63 & 0.76 & 1.02 & 0.94 \\
\hline ENBD & 0.65 & 0.69 & 0.86 & 0.76 & 0.69 \\
\hline ADCB & 1.39 & 1.36 & 1.54 & 1.34 & 1.41 \\
\hline Mashreq & 0.24 & 0.22 & 0.26 & 0.29 & 0.39 \\
\hline CBD & 0.51 & 0.67 & 0.70 & 0.67 & 0.28 \\
\hline RAK & 0.23 & 0.37 & 0.36 & 0.53 & 0.68 \\
\hline ADIB & 0.34 & 0.12 & - & - & - \\
\hline DIB & 0.16 & 0.25 & 0.28 & 0.30 & 0.36 \\
\hline Noor & - & 0.52 & 0.34 & 0.31 & 0.61 \\
\hline SIB & 0.72 & 1.09 & 1.13 & 1.00 & 1.02 \\
\hline AHB & 0.33 & 0.45 & 0.60 & 0.55 & 0.55 \\
\hline EIB & 0.82 & 0.72 & 1.10 & 0.76 & 0.51 \\
\hline
\end{tabular}

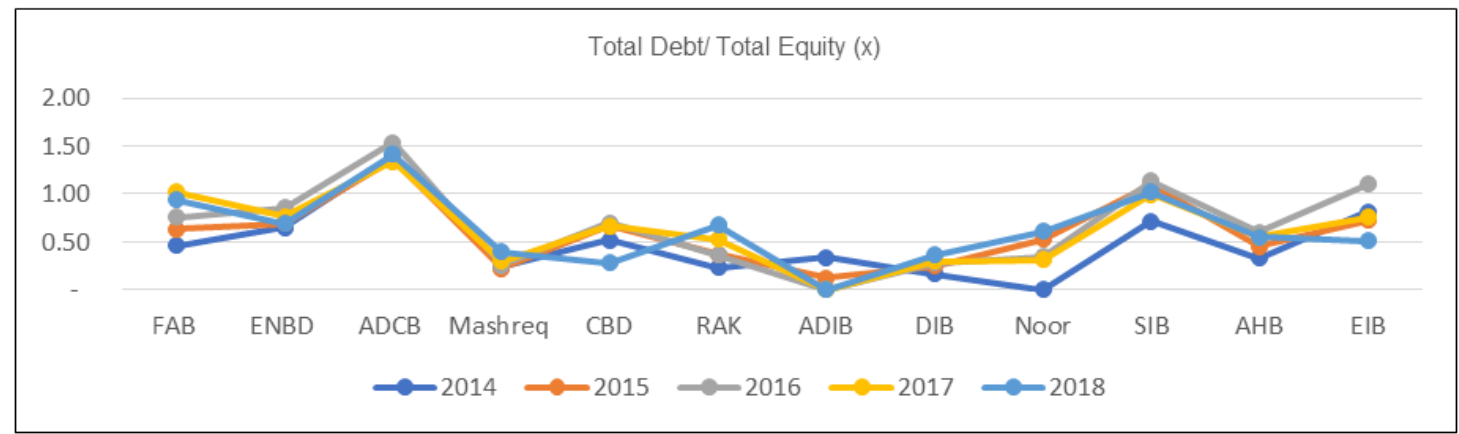

Fig-13: Graphical representation of Debt to Equity ratio for Conventional and Islamic Banks

\section{RESULTS AND ANALYSIS}

\begin{tabular}{|c|c|}
\hline Ratio & Results \\
\hline \multirow[t]{3}{*}{ Liquidity Ratios } & $\begin{array}{l}\text { The overall trend for loans to deposits is fairly consistent for conventional and } \\
\text { Islamic banks as seen in Figure } 1 \text { and Table } 1 \text {. In few occasions the conventional } \\
\text { banks have outnumbered the Islamic banks by higher lending to deposit ratio. It } \\
\text { also highlights that Islamic banks are conservative as far as the lending practices } \\
\text { are concerned. }\end{array}$ \\
\hline & $\begin{array}{l}\text { Lending to total asset ratios shows to what extent advances form part of the total } \\
\text { asset portfolio. While the trend is fluctuating, average advances for conventional } \\
\text { banks is lower than Islamic banks indicating that loans form higher proportion of } \\
\text { assets for Islamic banks. Conventional banks have diversified assets as compared to } \\
\text { Islamic banks as the latter may be restricted by their Shariah. The same has been } \\
\text { shown in Figure } 2 \text { and Table } 2 \text {. }\end{array}$ \\
\hline & $\begin{array}{l}\text { Liquid assets to total assets reflect the proportion of liquid assets (cash and bank } \\
\text { balances, marketable securities and other equivalents) held by the bank to its total } \\
\text { assets. In Figure } 3 \text { and Table } 3 \text {, it clearly shows wider fluctuations for Islamic } \\
\text { banks (ADIB, Noor, SIB, AHB and EIB) as compared to conventional banks. } \\
\text { Approximately, conventional banks have higher investment in liquid assets as } \\
\text { Islamic banks lack variety of investment options. The reason could also include } \\
\text { limitation on shariah compliant stocks where Islamic banks may invest for liquidity } \\
\text { purposes. }\end{array}$ \\
\hline \multirow[t]{2}{*}{ Efficiency Ratios } & $\begin{array}{l}\text { The trend for conventional banks and Islamic banks is similar for Return on } \\
\text { Average Assets as seen in Figure } 4 \text { and Table } 4 \text {. Approximately, all banks have } \\
\text { shown a downward movement except for ADCB, ENBD bank from the } \\
\text { conventional banks and ADIB, EIB bank from the Islamic banks. Hence the effect } \\
\text { for Return on Average Asset is considered neutral for both Islamic and } \\
\text { conventional banks. }\end{array}$ \\
\hline & $\begin{array}{l}\text { Clearly for Figure } 5 \text { and Table 5, Return on Average Equity is better for } \\
\text { conventional banks as compared to Islamic banks. This means that conventional } \\
\text { banks offer higher returns to the equity shareholder as compared to Islamic banks. }\end{array}$ \\
\hline
\end{tabular}


Manoj Kapur; Saudi J Bus Manag Stud, Jan., 2020; 5(1): 50-63

\begin{tabular}{|c|c|}
\hline Ratio & Results \\
\hline & $\begin{array}{l}\text { The general EPS of conventional banks are considered better those Islamic banks as } \\
\text { seen in Figure } 6 \text { and Table } 6 \text {. Further, even if one of the conventional banks } \\
\text { (Mashreq Bank) EPS is not considered since it is outside the average banking sector } \\
\text { EPS, the general earnings per share of conventional banks still fares better than } \\
\text { Islamic banks. This is in line with the findings for Return on Average Equity. }\end{array}$ \\
\hline \multirow[t]{2}{*}{ Asset Quality } & $\begin{array}{l}\text { It is important to note that author was unable to compute NIM ratio for certain } \\
\text { banks for few years due to unavailability of public data. Hence the NIM ratio for } \\
\text { certain years is kept at } 0 \% \text {. This has been represented in Figure } 7 \text { and Table } 7 \text {. } \\
\text { From the data available, the average NIM ratio for conventional banks was higher } \\
\text { than Islamic banks. } \\
\text { This is confirmatory to the finding that conventional banks have higher lending } \\
\text { activity than Islamic banks. It also confirms to the findings for NPL ratio which } \\
\text { foresees the conventional banks to have lower NPL than Islamic banks (Figure } 9 \\
\text { and Table 9). Further, even though conventional banks have lower NPL ratio, the } \\
\text { provision coverage is higher as compared to Islamic Banks, which is evident in } \\
\text { Table } 11 \text { and Figure 11). }\end{array}$ \\
\hline & $\begin{array}{l}\text { Total Equity have generally fallen over the years from } 2014 \text { to } 2018 \text { for } \\
\text { conventional and Islamic banks. However, conventional banks have higher equity } \\
\text { to total asset ratio as compared to Islamic banks as seen in Table } 8 \text { and Figure } 8 \text {. }\end{array}$ \\
\hline \multirow[t]{2}{*}{ Leverage Ratios } & $\begin{array}{l}\text { On an average, the Capital ratio for conventional banks is better than Islamic banks } \\
\text { (Table } 12 \text { and Figure 12). Islamic banks need to strengthen their capital base to } \\
\text { improve their capital base. }\end{array}$ \\
\hline & $\begin{array}{l}\text { The debt to equity ratio is higher for conventional banks indicating the higher risk } \\
\text { appetite for conventional banks as compared to Islamic banks (Table } 13 \text { and Figure } \\
\text { 13). This again proves the conservative business model of Islamic banks and the } \\
\text { restrictions imposed by the shariah to undertake high leverage. }\end{array}$ \\
\hline
\end{tabular}

\section{CONCLUSION}

The author has compared the performance of Islamic banks with the conventional banks from 2014 to 2018 (5 year period). Based on ratio analysis, the study found that there is significant difference between the performance of Islamic and conventional banks in terms of liquidity, efficiency, asset quality and leverage. The results indicate the conventional banks to be efficient in terms of return on equity, EPS and other key parameters. Even case of Net Interest Margin ratio, conventional banks has tended to outstrip Islamic banks. While Islamic banks have been conservative in advances due to shariah restrictions, conventional banks have larger risk appetite for lending activities. Another possible reason for comparatively low lending by the Islamic banks could include the financing of Islamic banks based on asset requirement as an underlying. The study also shows limited avenues for liquid asset investment products for Islamic Banks in the UAE. These challenges can be avoided by introducing new product development through Shariah approval. Islamic banks must also undertake better capital management practices in order to strengthen its capital base.

While the findings are useful, it must be considered that the time period under consideration is limited and further research must be conducted to further understand the deepening relation between Islamic and conventional banks in the UAE. Further research can be conducted by increasing the time horizon to include period before 2008 to understand if
Islamic banks have better ratios in the pre-vs-post economic crises.

\section{REFERENCES}

1. Kahf, M., \& Khan, T. (1992). Principles of Islamic financing. research paper, 16

2. CBUAE, FSR. (2018). Financial Stability Report 2018

3. Freeman, R.E. (1984). Strategic Management: A Stakeholder Approach, Boston, MA: Pitman.

4. Turker Measuring corporate social responsibility. (2009). A scale development study Journal of Business Research, 85, 411-427

5. Decker, O.S. (2004). Corporate social responsibility and structural change in financial services Managerial Auditing Journal, 19,712-728

6. Maignan, I., Ferrell O.C., Hult, G.T.(1999). Corporate citizenship: cultural antecedents and business benefits Journal of the Academy of Marketing Science, 27, 455-469

7. Parashar. (2010). Sat Paul - How Did Islamic Banks Do During Global Financial Crisis? (September 30, 2010). Banks and Bank Systems, 5(4), 54-62.

8. Samad. (2004). Performance of interest free Islamic banks vis-à-vis interest based conventional banks of Bahrain. IIUM Journal of Economic and Management, 12(2), 1-15

9. Srairi, S.A. (2010). Cost and profit efficiency of Islamic and conventional banks in GCC. Journal of productivity analysis, 34(1),45-62 
Manoj Kapur; Saudi J Bus Manag Stud, Jan., 2020; 5(1): 50-63

10. Zaki, E. R. B. (2012). Analysis of Financial Crisis in UAE Financial Markets. International Research Journal of Finance and Economics, 83.

11. Ibrahim, M. (2015). Measuring the Financial Performance of Islamic Banks. Journal of Applied Finance and Banking, 5(3), 93.

12. Kim, M., \& Kim, I. W. (1997). The structure-profit relationship of commercial banks in South Korea and the United States: A comparative study. Multinational Business Review, 5(2), 81.

13. Zimmerman, G. C. (1996). Factors influencing community bank performance in California. Economic Review-Federal Reserve Bank of San Francisco, 26-40.

14. Al-Tamimi, H., \& Hussein, A. (2010). Factors influencing performance of the UAE Islamic and conventional national banks. Global Journal of Business Research, 4(2), 1-9.

15. Aman, A., Sharif, S., \& Arif, I. (2016). Comparison of Islamic banks with conventional banks: Evidence from an emerging market. Journal of Management Sciences, 3(1), 24-33.

16. Bank for International Settlements. (2008). Principles for Sound Liquidity Risk Management and Supervision.

17. Wozniewska, G. (2008). Methods of measuring the efficiency of commercial banks: an example of polish banks. Ekonomika/Economics, 84.

18. Abata, M. A. (2014). Asset quality and bank performance: A study of commercial banks in Nigeria. Research Journal of Finance and Accounting, 5(18), 39-44.

19. D'Hulster, K. (2009). The leverage ratio: A new binding limit on banks.

\footnotetext{
Annual Financial Statement of the conventional and Islamic banks in the UAE

1) First Gulf Bank (FGB), 2014

2) National Bank of Abu Dhabi (NBAD), 2014

3) First Gulf Bank (FGB), 2015

4) National Bank of Abu Dhabi (NBAD), 2015

5) First Abu Dhabi Bank (FAB), 2016

6) First Abu Dhabi Bank (FAB), 2017

7) First Abu Dhabi Bank (FAB), 2018

8) Emirates NBD (ENBD), 2014

9) Emirates NBD (ENBD), 2015

10) Emirates NBD (ENBD), 2016

11) Emirates NBD (ENBD), 2017

12) Emirates NBD (ENBD), 2018

13) Abu Dhabi Commercial Bank (ADCB), 2014

14) Abu Dhabi Commercial Bank (ADCB), 2015

15) Abu Dhabi Commercial Bank (ADCB), 2016

16) Abu Dhabi Commercial Bank (ADCB), 2017

17) Abu Dhabi Commercial Bank (ADCB), 2018

18) Mashreq Bank, 2014

19) Mashreq Bank, 2015

20) Mashreq Bank, 2016

21) Mashreq Bank, 2017

22) Mashreq Bank, 2018

23) Commercial Bank Dubai (CBD), 2014
}

24) Commercial Bank Dubai (CBD), 2015

25) Commercial Bank Dubai (CBD), 2016

26) Commercial Bank Dubai (CBD), 2017

27) Commercial Bank Dubai (CBD), 2018

28) RAK Bank (RAK), 2014

29) RAK Bank (RAK), 2015

30) RAK Bank (RAK), 2016

31) RAK Bank (RAK), 2017

32) RAK Bank (RAK), 2018

33) Abu Dhabi Islamic Bank (ADIB), 2014

34) Abu Dhabi Islamic Bank (ADIB), 2015

35) Abu Dhabi Islamic Bank (ADIB), 2016

36) Abu Dhabi Islamic Bank (ADIB), 2017

37) Abu Dhabi Islamic Bank (ADIB), 2018

38) Dubai Islamic Bank (DIB), 2014

39) Dubai Islamic Bank (DIB), 2015

40) Dubai Islamic Bank (DIB), 2016

41) Dubai Islamic Bank (DIB), 2017

42) Dubai Islamic Bank (DIB), 2018

43) Noor Bank (Noor), 2014

44) Noor Bank (Noor), 2015

45) Noor Bank (Noor), 2016

46) Noor Bank (Noor), 2017

47) Noor Bank (Noor), 2018

48) Sharjah Islamic Bank (SIB), 2014

49) Sharjah Islamic Bank (SIB), 2015

50) Sharjah Islamic Bank (SIB), 2016

51) Sharjah Islamic Bank (SIB), 2017

52) Sharjah Islamic Bank (SIB), 2018

53) Al Hilal Bank (AHB), 2014

54) Al Hilal Bank (AHB), 2015

55) Al Hilal Bank (AHB), 2016

56) Al Hilal Bank (AHB), 2017

57) Al Hilal Bank (AHB), 2018

58) Emirates Islamic Bank (EIB), 2014

59) Emirates Islamic Bank (EIB), 2015

60) Emirates Islamic Bank (EIB), 2016

61) Emirates Islamic Bank (EIB), 2017

62) Emirates Islamic Bank (EIB), 2018 